\title{
DO CARBONATE KARST TERRAINS AFFECT THE GLOBAL CARBON CYCLE?
}

\author{
ALI KRAŠKA OBMOČJA NA KARBONATIH VPLIVAJO NA \\ GLOBALNO KROŽENJE OGLJIKA?
}

\author{
Jonathan B. MARTIN ${ }^{1}$, Amy BROWN ${ }^{1}$ \& John EZELL ${ }^{1}$
}

\begin{abstract}
UDC 551.44:546.26

Jonathan B. Martin, Amy Brown \& John Ezell: Do carbonate karst terrains affect the global carbon cycle?

Carbonate minerals comprise the largest reservoir of carbon in the earth's lithosphere, but they are generally assumed to have no net impact on the global carbon cycle if rapid dissolution and precipitation reactions represent equal sources and sinks of atmospheric carbon. Observations of both terrestrial and marine carbonate systems indicate that carbonate minerals may simultaneously dissolve and precipitate within different portions of individual hydrologic systems. In all cases reported here, the dissolution and precipitation reactions are related to primary production, which fixes atmospheric $\mathrm{CO}_{2}$ as organic carbon, and the subsequent remineralization in watersheds of the organic carbon to dissolved $\mathrm{CO}_{2}$. Deposition of carbonate minerals in the ocean represents a flux of $\mathrm{CO}_{2}$ to the atmosphere. The dissolution of oceanic carbonate minerals can act either as a sink for atmospheric $\mathrm{CO}_{2}$ if dissolved by carbonic acid, or as a source of $\mathrm{CO}_{2}$ if dissolved through sulfide oxidation at the freshwater-saltwater boundary. Since dissolution and precipitation of carbonate minerals depend on ecological processes, changes in these processes due to shifts in rainfall patterns, earth surface temperatures, and sea level should also alter the potential magnitudes of sources and sinks for atmospheric $\mathrm{CO}_{2}$ from carbonate terrains, providing feedbacks to the global carbon cycle that differ from modern feedbacks.

Keywords: Global carbon cycle, carbonate terrains, organic carbon fixation, remineralization, carbonate mineral dissolution, carbonate mineral precipitation.
\end{abstract}

\author{
Izvleček \\ UDK 551.44:546.26 \\ Jonathan B. Martin, Amy Brown \& John Ezell: Ali kraška \\ območja na karbonatih vplivajo na globalno kroženje oglji- \\ $k a$ ?
}

Kljub temu, da so karbonati so največje skladišče ogljika v litosferi, velja splošna domneva, da nimajo pomembnega vpliva na globalno kroženje ogljika, ker sta raztapljanje in izločanje karbonatov uravnotežen izvor in ponor atmosferskega ogljika. Kopenski in morski karbonati se v izbranem hidrološkem sistemu sočasno raztapljajo in izločajo. V vseh primerih, ki jih obravnavamo, sta raztapljanje in izločanje povezana s primarno produkcijo, ki uskladišči atmosferski $\mathrm{CO}_{2}$ kot organski ogljik in prehajanje organskega ogljika $\mathrm{v}$ raztoljeni $\mathrm{CO}_{2}$, ob remineralizaciji v kraških vodonosnikih. Odlaganje karbonatov v morju predstavlja prehod $\mathrm{CO}_{2} \mathrm{v}$ ozračje. Raztapljanje karbonatov je ponor $\mathrm{CO}_{2}$, če raztaplja ogljikova kislina oziroma izvor $\mathrm{CO}_{2}$, če raztapljanje poteka preko oksidacije sulfida na meji med slano in sladko vodo. Ker je raztapljanje in izločanje odvisno od številnih okoljskih parametrov, lahko spremembe okolja, kot so intenziteta in pogostost padavin, temperatura površja in spremembe morske gladine, spremenijo velikosti izvorov in ponorov atmosferskega $\mathrm{CO}_{2}$ iz kraških procesov in vodijo $\mathrm{v}$ nove povratne zanke $\mathrm{v}$ kroženju ogljika, ki se razlikujejo od današnjih.

Ključne besede: globalno kroženje ogljika, skladiščenje organskega ogljika, remineralizacija, raztapljanje karbonatov, izločanje karbonatov.

\footnotetext{
${ }^{1}$ University of Florida, Department of Geological Sciences, PO Box 112120, 241 Williamson Hall, Gainesville Florida 32605-2120, 352-392-9294, e-mail: jbmartin@ufl.edu, amy.brown@ufl.ed, ezelljohn1@gmail.com
}

Received/Prejeto: 20.3 .2013 


\section{INTRODUCTION}

Models of the global carbon cycle attempt to identify the magnitude of carbon in all earth, ocean, and atmospheric reservoirs, quantify the fluxes between those reservoirs, and assess chemical transformations of the carbon within reservoirs and in the flow paths between reservoirs (e.g., Solomon et al. 2007, Fig. 1). Estimates of carbon cycling

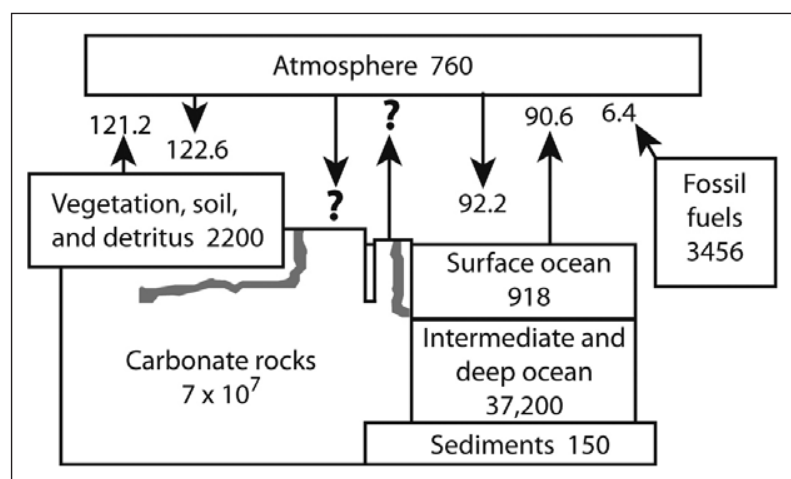

Fig. 1: A generalized version of the modern global carbon cycle model. The numbers in the box are in petagrams $\left(10^{15} \mathrm{~g}\right) \mathrm{C}(\mathrm{Pg}$ C) and the fluxes are PgC/yr and include fluxes from anthropogenic sources. For simplicity, the model shows only fluxes between the atmosphere and biosphere and oceans. The grey polygons within the carbonate rock reservoir represent karst features including caves, conduits and blue holes. Modified from Solomon et al. (2007) and Kump et al. (2010).

are particularly important because the concentration of atmospheric $\mathrm{CO}_{2}$ is thought to have approximately doubled over the past few hundred years due to land use changes and increased fluxes of carbon from the terrestrial biosphere and burning of fossil fuels with industrialization (Solomon et al. 2007). Atmospheric $\mathrm{CO}_{2}$ concentration has been directly measured over the past 67 years and these measurements show that the partial pressure of $\mathrm{CO}_{2}$ in the earth's atmosphere has increased from around $318 \mathrm{ppmv}$ to the most recent values of around 395 ppmv (Keeling \& Whorf 2005). This increase is similar in magnitude to variations in $\mathrm{CO}_{2}$ partial pressure that occurred throughout Pleistocene glacial-interglacial cycles as estimated from $\mathrm{CO}_{2}$ concentrations measured from the Vostok ice core in Antarctica (Falkowski et al. 2000). Changing land use and burning of fossil fuels are estimated to have increased annual fluxes of carbon to the atmosphere by approximately 8 petagrams $\left(10^{15} \mathrm{~g}\right)$ of $\mathrm{C}$ per year $(\mathrm{PgC} / \mathrm{yr})$, an increase of slightly more than $4 \%$ over the pre-industrial fluxes of carbon (Solomon et al. 2007). This new flux of carbon, and the increase in atmospheric carbon abundance, as well as associated increases in the oceans, are presumed to lead to a variety of environmental effects, including global warming (Mann et al. 1998), ocean acidification (Orr et al. 2005, HoeghGuldberg et al. 2007), and melting of land-based glaciers (Alley et al. 2005, Overpeck et al. 2006). Melting of landbased glaciers, along with thermal expansion, lead to rising sea level (Lambeck et al. 2002).

The major pre-industrial fluxes of carbon between reservoirs include exchange between the atmosphere and terrestrial biosphere, which was approximately 120 $\mathrm{PgC} / \mathrm{yr}$ and between the atmosphere and surficial ocean, which was approximately $70 \mathrm{PgC} / \mathrm{yr}$ (Solomon et al. 2007). Of the reservoirs of carbon that typically are included as participating in global carbon cycling, the ocean is the largest reservoir, containing approximately $3.8 \times 10^{4} \mathrm{Pg} \mathrm{C}$, compared with the current abundance of carbon in the atmosphere of around $7.6 \times 10^{2} \mathrm{Pg} \mathrm{C}$ (Fig. 2). The other major reservoir of carbon that partici-

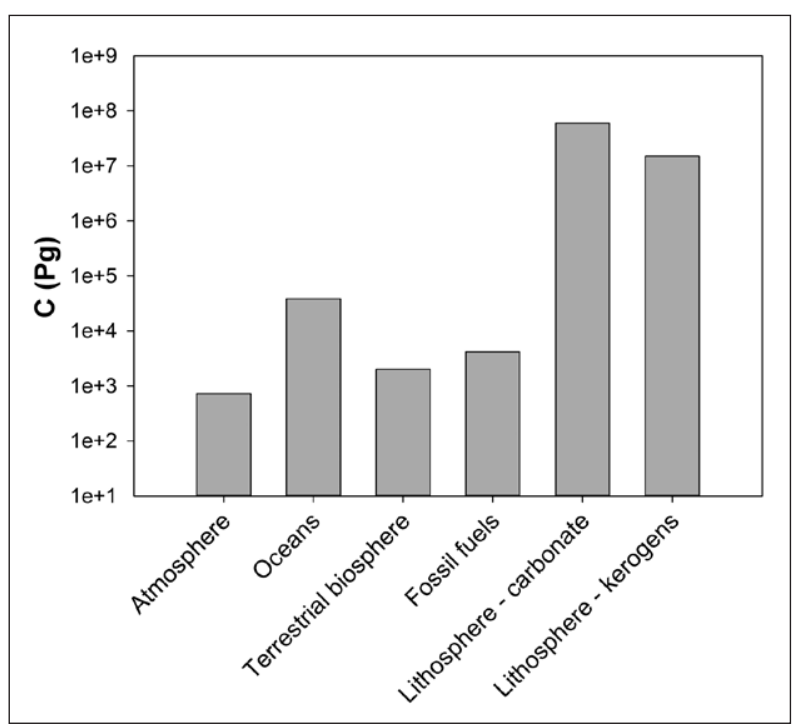

Fig. 2: Histogram of the magnitude of carbon stored in various global reservoirs showing carbonate terrains with the largest abundance of carbon (data from Falkowski et al. 2000).

pates in carbon cycling is the terrestrial biosphere, which is estimated to contain around $2.3 \times 10^{3} \mathrm{Pg} \mathrm{C}$. By far, the largest reservoir of carbon in the earth system is carbonate rocks, which contain as much as $4 \times 10^{7} \mathrm{Pg} \mathrm{C}$, or more than three orders of magnitude more carbon than the oceanic reservoir (Fig. 2).

These carbonate rocks crop out over approximately $20 \%$ of the earth's ice-free surface (e.g., Ford \& Williams 2007), but may be mantled by soils containing variable amount of organic carbon. Carbonate rocks undergo dissolution due to the action of $\mathrm{CO}_{2}$, which when dissolved 
and hydrated forms carbonic acid, the most common weathering agent for all rock types, including carbonate as well as silicate rocks. The $\mathrm{CO}_{2}$ driving this dissolution can come from surface waters in equilibrium with atmospheric $\mathrm{CO}_{2}$, or from the remineralization of the organic carbon which may increase $\mathrm{CO}_{2}$ concentrations over that of the atmosphere resulting in increased dissolution. These dissolution reactions result in the transformation of atmospheric $\mathrm{CO}_{2}$ into dissolved bicarbonate, thereby acting as a sink for atmospheric $\mathrm{CO}_{2}$. Since carbonate minerals tend to be more soluble, with faster dissolution kinetics, than silicate minerals, they may be expected to play a larger role in dissolution reactions than silicate minerals and thus sequestration of atmospheric $\mathrm{CO}_{2}$. Carbonate dissolution is neglected in most global carbon cycle models, however, because precipitation of carbonate minerals also liberates $\mathrm{CO}_{2}$, resulting in no net change in the cycle (Berner et al. 1983). No net change in atmospheric $\mathrm{CO}_{2}$ would occur only if both precipitation and dissolution occur at the same rates within the timescale of interest (e.g., Liu et al. 2010, 2011).

Recent work in karst systems has suggested that at small spatial and short time scales, cycling of carbonate minerals could be more important for drawdown of atmospheric carbon than silicate dissolution when carbon is buried as solid mineral and organic phases (e.g., Liu et al. 2010, 2011). For example, rapid precipitation of marine carbonates at elevated sea level and their dissolution at low sea level during glacial times may, in part, control atmospheric $\mathrm{CO}_{2}$ concentrations at glacial-interglacial timescales (Berger 1982; Mylroie 1993). The soluble nature of carbonate minerals can lead to large dissolution voids (speleogenesis and formation of karstic features), reflecting the exchange of carbon between the atmosphere and solid carbonate minerals. Speleogenesis also impacts other valuable resources such as potable water and ecosystem services that rely on karst waters (e.g., Ford \& Williams 2007), reflecting the importance of this process on human social systems. Consequently, understanding how dissolution and reprecipitation of carbonate minerals may be linked to the global carbon cycle is critical to evaluations of impact to ecological function and water resources during changes to the global climate.

In the following paper, we present case studies that link reactions and exchange with atmospheric $\mathrm{CO}_{2}$ in karst hydrologic processes with carbonate dissolution and precipitation. The case studies represent both terrestrial and marine systems. In all cases, the reactions of the carbonate mineral phases are linked to ecological processes, including photosynthetic fixation of atmospheric $\mathrm{CO}_{2}$ at the land surface and in subaquatic vegetation, and remineralization of the fixed carbon. Case studies presented here are used to develop a general understanding of processes that provide sources or sinks of atmospheric $\mathrm{CO}_{2}$ through reactions with solid carbonate phases. The case studies are somewhat restricted geographically and through time, which limits our ability to extract global magnitudes of the fluxes from the processes that are identified as sources or sinks of atmospheric $\mathrm{CO}_{2}$.

\section{ATMOSPHERIC $\mathrm{CO}_{2}$ FLUXES IN SILICATE AND CARBONATE WEATHERING}

Silicate weathering reactions can be represented by the following general reaction mechanism:

$$
\mathrm{CaSiO}_{3(\mathrm{~s})}+2 \mathrm{CO}_{2(\mathrm{~g})}+\mathrm{H}_{2} \mathrm{O} \rightarrow \mathrm{Ca}^{2+}+2 \mathrm{HCO}_{3}^{-}+\mathrm{SiO}_{2(\mathrm{~s})}
$$

in which a $\mathrm{Ca}$ silicate mineral (here shown as wollastonite) reacts with carbonic acid formed by the hydration of atmospheric $\mathrm{CO}_{2}$ and water to generate dissolved calcium and bicarbonate, along with silica. The dissolved calcium and bicarbonate can react to form calcium carbonate (either aragonite or calcite), water, and $\mathrm{CO}_{2}$ according to

$$
\mathrm{Ca}^{2+}+2 \mathrm{HCO}_{3}^{-} \rightarrow \mathrm{CaCO}_{3(\mathrm{~s})}+\mathrm{H}_{2} \mathrm{O}+\mathrm{CO}_{2(\mathrm{~g})}
$$

The silica in reaction 1 and carbonate mineral in reaction 2 are commonly precipitated by autotrophic and heterotrophic organisms in the oceans, and to a lesser degree in lakes and other terrestrial water systems. The resulting solid phases commonly sink to the bottom of the water bodies in which they have formed, thereby sequestering the silica and carbon in a process referred to as the biological pump. The summation of reactions 1 and 2 yields the following reaction

$\mathrm{CaSiO}_{3}+\mathrm{CO}_{2} \leftrightarrow \mathrm{CaCO}_{3}+\mathrm{SiO}_{2}$

which shows explicitly that for each mole of $\mathrm{Ca}$ silicate minerals dissolved, a mole of atmospheric $\mathrm{CO}_{2}$ is sequestered through the biologic pump. The forward reaction, which is a low-temperature weathering reaction, tends to be faster than the reverse reaction, which occurs at metamorphic temperatures pressures. Consequently, the weathering of silicate minerals is typically considered an 
important control in the sequestration of atmospheric $\mathrm{CO}_{2}$ and has been suggested to link major tectonic events, such as the uplift of the Himalayas, to long-term changes in atmospheric $\mathrm{CO}_{2}$ partial pressures and global climate (Raymo et al. 1988).

The dissolution of carbonate minerals by carbonic acid may be considered by the following reaction

$$
\mathrm{CaCO}_{3(\mathrm{~s})}+\mathrm{CO}_{2(\mathrm{~g})}+\mathrm{H}_{2} \mathrm{O} \rightarrow \mathrm{Ca}^{2+}+2 \mathrm{HCO}_{3}^{-}
$$

in which carbonic acid is formed by hydration of one mole of atmospheric $\mathrm{CO}_{2}$ and dissolves carbonate minerals to generate dissolved calcium and bicarbonate. This reaction differs from silicate dissolution (e.g., reaction 3 ) because the reaction products remain dissolved so that the reverse of reaction 4 (e.g., reaction 2) releases one mole of atmospheric $\mathrm{CO}_{2}$. Consequently, the net result of reactions 2 and 4 is that $\mathrm{CO}_{2}$ is not permanently sequestered from the atmosphere, and instead is returned to the atmosphere during precipitation of the calcium carbonate minerals. The reaction rates of the forward and reverse reactions are similar, compared with the large variations in forward and reverse reaction rates of reaction 3, and thus carbonate minerals are thought to have no net effect on the global carbon cycle (Berner et al. 1983). Dissolution and precipitation of marine carbonates is balanced at a global scale only over glacialinterglacial time scales because of differences in the timing of their deposition and precipitation with sea level variations (Mylroie 1993). If the net dissolution and precipitation reactions differ locally, imbalances between reactions 2 and 4 could impact local carbon cycling (e.g., Liu et al. 2010, 2011).

\section{CASE STUDIES}

Florida - a terrestrial system. Limestone of the Floridan Aquifer, an Eocene aged eogenetic (Vacher \& Mylroie 2002) karst aquifer, is exposed across a small window of north-central Florida, but elsewhere throughout the region, the aquifer is confined by a siliciclastic unit called the Hawthorn Group (Scott 1988, Scott 1992). The boundary between the confined and unconfined Floridan Aquifer is locally referred to as the Cody Scarp and represents an erosional edge of the Hawthorn Group rocks. This boundary provides an important control on the hydrology and hydrogeology of the region by separating terrains that are characterized by large amounts of surface runoff from areas in which most surface water sinks into the Floridan Aquifer (Gulley et al. 2012). The composition of surface water draining off of the Hawthorn Group tends to be enriched in dissolved organic carbon. Oxidation of this dissolved organic carbon forms $\mathrm{CO}_{2}$, which hydrates to carbonic acid and dissolves carbonate minerals (reaction 2). Although this $\mathrm{CO}_{2}$ is not directly dissolved from atmospheric $\mathrm{CO}_{2}$, its ultimate source is atmospheric $\mathrm{CO}_{2}$ that has been photosynthetically fixed to organic carbon, and thus also remains a sink of atmospheric $\mathrm{CO}_{2}$.

The tendency for water to dissolve or precipitate mineral phases is commonly evaluated based on calculations of the saturation index, a measure of the saturation state of the water with respect to mineral phases. The saturation index is defined here as $\log \left(\mathrm{IAP} / \mathrm{K}_{\mathrm{sp}}\right)$, where IAP is the ion activity product of solutes in the water that take part in mineral dissolution reactions, and the $\mathrm{K}_{\mathrm{sp}}$ is the thermodynamic equilibrium constant relative to the mineral phase of the reaction, in this case calcite (e.g., Stumm \& Morgan 1996). When the IAP $=\mathrm{K}_{\mathrm{sp}}$, the system is in equilibrium and the $\log \left(\mathrm{IAP} / \mathrm{K}_{\mathrm{sp}}\right)$ equals zero. Negative values indicate undersaturation with respect to the particular mineral and a tendency for that mineral phase to dissolve and positive values indicate supersaturation and a tendency for that mineral to precipitate.

Along the Cody Scarp in north-central Florida, flow of organic carbon and $\mathrm{CO}_{2}$-rich water into the Floridan Aquifer drives dissolution of the aquifer (Martin \& Dean 2001). Although all of the $\mathrm{CO}_{2}$ dissolved in the water could ultimately react with carbonate minerals, the newly identify mechanism for calcite dissolution results from flooding surface water flowing into spring vents that normally discharge to rivers during baseflow conditions (Gulley et al. 2011). These events are common at springs along the Suwannee River, particularly springs in the unconfined Floridan Aquifer immediately downstream from the Cody Scarp.

One such event at the Peacock Spring system, located approximately $40 \mathrm{~km}$ downstream of the scarp allowed water that was characterized by saturation indices with respect to calcite of less than -5 to flow into the Floridan Aquifer (Fig. 3). River water flowed into the spring during the flood for approximately 3 weeks as shown by the presence of low conductivity river water in the spring system, which has relatively constant specific conductivity value of approximately $400 \mu \mathrm{S} / \mathrm{cm}$ during base flow. The rapid decrease of specific conductivity during the rising limb of the hydrograph reflects 
the initial intrusion of river water and the rapid return to elevated specific conductivity during the recession limb reflects renewed discharge from the spring. Grab samples collected from the Suwannee River and two karst windows (Orange Grove Sink and Challenge Sink) connected to the Peacock Spring system indicate that the water flowing into the subsurface remained undersaturated with respect to calcite throughout the flood and recession curve although the saturation index increased through time to values of around -1 (Fig. 3). Since the saturation index did not indicate a return to equilibrium during the recession, the water is unlikely to have dissolved enough calcite to reach equilibrium with the minerals making up the Floridan Aquifer. Nonetheless, the increase in the value of the saturation index, and its low initial value, suggests that some calcite was dissolved during this flood. Dissolution of this calcite would occur through reaction 4 , sequestering atmospheric $\mathrm{CO}_{2}$ as dissolved bicarbonate. This bicarbonate could ultimately be transported to the ocean, thereby impacting its alkalinity.

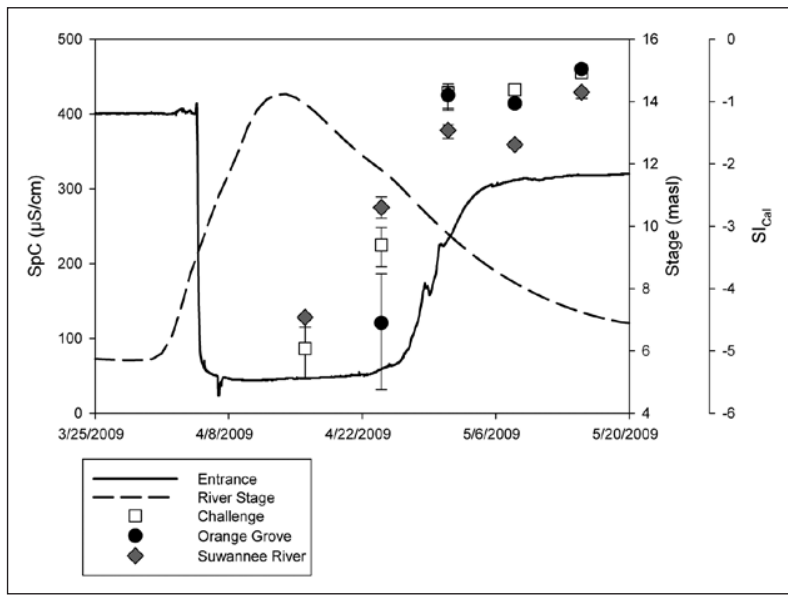

Fig. 3: Time series plot of stage of Suwannee River near Peacock Springs (dashed line), variation in specific conductivity water at the entrance to Peacock Springs (solid line), and the saturation index of the Suwannee River water (gray diamonds) and water at two sink holes connected to Peacock Springs via conduits: Orange Grove Sink (black dots) and Challenge Sink (white squares). Modified from Gulley et al. (2011).

Numerous springs discharge from the unconfined portion of the Floridan Aquifer in north-central Florida (Rosenau et al. 1977, Scott et al. 2004) and during times of discharge, the water typically has low dissolved organic carbon concentrations, elevated $\mathrm{P}_{\mathrm{CO} 2}$ values, and is at equilibrium with calcite within the Floridan Aquifer. The elevated $\mathrm{P}_{\mathrm{CO}_{2}}$ in the spring water typically degasses to the atmosphere, which can drive the water toward supersaturation with respect to carbonate minerals, including calcite (M. Khadka, Pers. comm.). In addition, metabolism of in-stream submerged vegetation reduces the $\mathrm{CO}_{2}$ concentrations during daytime photosynthesis (de Montety et al. 2011). This metabolism also drives cycling of other solutes, in particular, nutrient concentrations (e.g., Heffernan \& Cohen 2011, Cohen et al. 2012). These changes in the chemical composition of the spring runs alter the saturation state of the water with respect to calcite at a 24 hour (i.e., diel) frequencies (Fig. 4). The

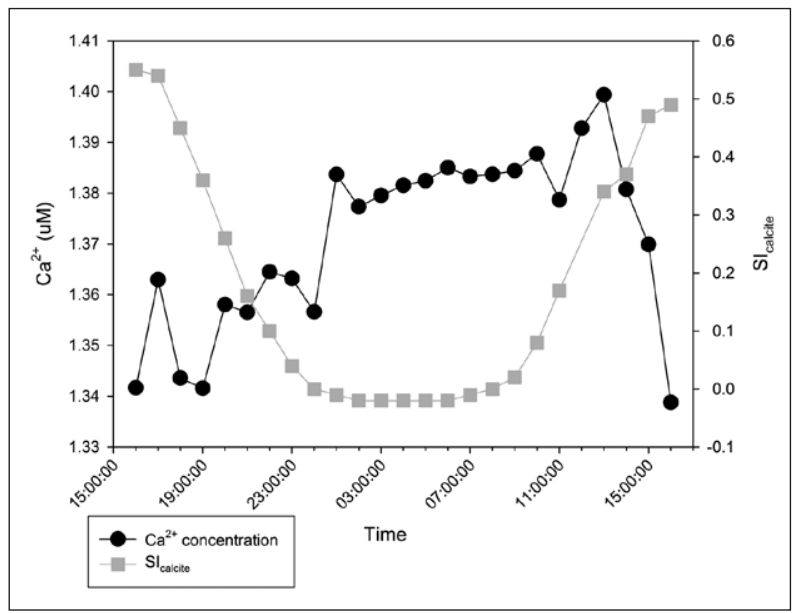

Fig. 4 : Time series measurements of the $\mathrm{Ca}^{2+}$ concentration and the saturation index with respect to calcite in the Ichetucknee River, Florida between 16:00 hrs on March 26, 2009 and 16:00 hrs March 27, 2009 (Modified from de Montety et al. 2011).

saturation state always remains supersaturated, and temporal variations in saturation states show an inverse relationship to changes observed in specific conductivity, which are largely driven by changes in the $\mathrm{Ca}^{2+}$ concentrations (de Montety et al. 2011). These changes suggest that calcite precipitates in the spring runs as $\mathrm{CO}_{2}$ is removed through degassing to the atmosphere and uptake by the submerged vegetation. Furthermore, the precipitated calcite is not balanced by subsequent dissolution in the river since the river never has a saturation index reflecting undersaturation.

These studies from the terrestrial freshwater system of north-central Florida indicate that carbonate minerals (largely calcite) will both dissolve and precipitate, depending on the particular location within the system. Whether dissolution or precipitation is the primary process depends largely on whether atmospheric and/or dissolved inorganic carbon is being fixed during photosynthesis, or if dissolved organic carbon is being respired to $\mathrm{CO}_{2}$. Regardless of the pathway, the ultimate source of carbon that precipitates as carbonate minerals is atmospheric, but precipitation provides a source of $\mathrm{CO}_{2}$ 
to the atmosphere (e.g., reaction 2), while dissolution of carbonate through the oxidation of organic carbon sequesters carbon from the atmosphere (e.g., reaction 4). The relative magnitude of atmospheric carbon that is released or sequestered by these processes is unknown. Both sequestration and release of carbon to the atmosphere occur simultaneously at different locations within a single hydrologic system, indicating that the magnitude of $\mathrm{CO}_{2}$ lost from or gained by the atmosphere through dissolution and precipitation of carbonate minerals in terrestrial carbonate karst terrains could be balanced at small spatial and temporal scales. The north Florida carbonate platform is currently being denuded as shown by a net flux of bicarbonate to the oceans and geomorphic modeling (Opdyke et al. 1984, Adams et al. 2010), indicating this system currently represents a long term sink for atmospheric $\mathrm{CO}_{2}$.

The Bahamas - a marine system. The bicarbonate that is generated during mineral weathering (e.g., reactions 1, 3 and 4) is carried to the oceans through river systems and groundwater. This bicarbonate is an important control on alkalinity of the oceans along with circulation through mid-ocean ridge crests and flanks. The bicarbonate may precipitate as solid carbonate by microorganisms (e.g., foraminifera and cocolithophorids) and by calcifying algae such as Halimeda and Penicillus and to a smaller extent by reef-forming corals. The microorganisms are deposited on the seafloor and buried, but much of the calcifying algae form deposits of large carbonate banks such as the Bahamas (Sealey 2006). Regardless of the ultimate depositional site for these carbonate minerals, for each mole of calcium carbonate deposited, one mole of $\mathrm{CO}_{2}$ is released to the atmosphere (reaction 2), a process referred to by Berger (1982) as the coral reef hypothesis. Carbonate banks are not solely sites of deposition, however; much dissolution occurs in the carbonate systems as shown by widespread cave formation, such as flank margin and vertical caves (Mylroie et al. 1995). At modern sea level, vertical caves are commonly filled with water, in which case they are referred to as blue holes in the Bahamas and cenotes in the Yucatan (Mylroie et al. 1995, Schwabe \& Herbert 2004). Dissolution in carbonate platforms, if resulting from carbonic acid generated through dissolution of atmospheric $\mathrm{CO}_{2}$, or remineralization of organic carbon that had as its ultimate source $\mathrm{CO}_{2}$ fixed from the atmosphere, should sequester atmospheric carbon as bicarbonate in the oceans.

Blue holes (and cenotes) are open to the surface and thus act as repositories for organic carbon generated within surface ecological systems. Where deep enough, these features may penetrate through the fresh-water lens of low-lying carbonate platforms. The contact between the fresh water and salt water underlying the fresh-water lens traps organic carbon because of density differences in the two different salinity waters. Remineralization of this organic carbon can consume all the available oxygen at that horizon. The underlying saltwater typically has sulfate concentrations of seawater, which are elevated over those of the freshwater and can be used as a terminal electron acceptor for organic carbon remineralization following the consumption of oxygen (Stoessell et al. 1989). Sulfate reduction produces hydrogen sulfide, which is re-oxidized to sulfate when diffused or advected into portions of the water column containing oxygen, thereby generating sulfuric acid, reducing the saturation state of the water within the blue hole, and potentially driving dissolution of the carbonate walls of the blue hole by reaction mechanisms such as

$\mathrm{H}_{2} \mathrm{~S}+2 \mathrm{O}_{2}+\mathrm{CaCO}_{3}(\mathrm{~s}) \rightarrow \mathrm{SO}_{4}^{2-}+\mathrm{Ca}^{2+}+\mathrm{H}_{2} \mathrm{O}+\mathrm{CO}_{2}$

This mechanism for cave formation was perhaps first recognized in terrestrial systems at Carlsbad Caverns, New Mexico (e.g., Hill 1987, Hill 1990).

Dissolution requires that the undersaturated water comes into contact with the wall rock of the blue hole and thus exchange must occur between water within the blue holes and the wall rock. In terrestrial systems, hydrologic gradients can be driven by topography such that during flooding, the hydraulic head within karst features (e.g., caves and conduits) may be greater than the hydraulic head with in the pore spaces of the aquifer (Martin \& Dean 2001). Alternatively, water may flow upward from geothermal heating, as in the case of Carlsbad Cavern, where sulfur is introduced into the cave system through migration of sulfur in oil field brines in the neighboring Permian Basin (Hill 1987, Hill 1990). Topographic relief of carbonate platforms is rarely sufficient to drive exchange between voids such as blue holes and the surrounding matrix porosity, although geothermal heating may drive vertical circulation in carbonate platforms (Kohout 1965, Whitaker \& Smart 1990, Martin \& Moore 2008).

Sufficiently large differences in hydraulic head to drive small-scale (e.g., a few meters) exchange between blue holes and the surrounding matrix have been shown to result from tidal lags between water in the matrix porosity and water in blue holes that are connected to the ocean via conduits (Whitaker \& Smart 1997, Martin et al. 2012). The tidal lags result from differences in lower hydraulic conductivity in the matrix porosity than in the conduits. Exchange allows water undersaturated with respect to carbonate minerals from dissociation of either carbonic acid or sulfuric acid to contact and dissolve the minerals. Whether dissolution occurs from carbonic or sulfuric acid is critical to the cycling of at- 
mospheric carbon within these systems. Dissolution by carbonic acid acts to sequester $\mathrm{CO}_{2}$ from the atmosphere (e.g., reaction 4) in carbonate platforms, counteracting the source of atmospheric $\mathrm{CO}_{2}$ from precipitation of carbonate minerals (e.g., reaction 2). In contrast, carbonate mineral dissolution caused by sulfuric acid produced through the oxidation of sulfide (reaction 5) provides $\mathrm{CO}_{2}$ to the atmosphere that otherwise would have been sequestered as carbonate minerals via the biological pump.

An example of how sulfur may play a role in dissolution of carbonate minerals is shown by variations in the specific conductivity and sulfide concentrations through tidal cycles at the edge and in the center of Ink Well Blue Hole on San Salvador Island Bahamas (Fig. 5). Ink Well

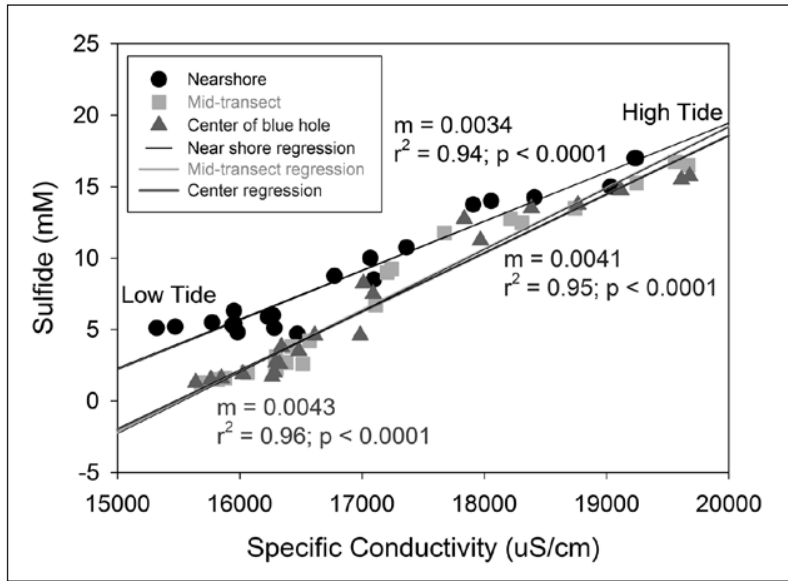

Fig. 5: Sulfide concentrations versus specific conductivity at Ink Well Blue Hole, San Salvador Island, Bahamas. The data were measured on samples collected at a constant depth of $2 \mathrm{~m}$ below the water level through a tidal cycle in a transect from the center of the blue hole (gray triangles) to the edge (black dots) with a sample point intermediate between the other two sampling points (gray squares). Samples with the low specific conductivity and sulfide concentrations were sampled at low tide and with high specific conductivity at high tide. The lines represent linear regression of the data from each sample site, with the slope $(m), r^{2}$ and $p$ values shown for each regression.

Blue Hole, which has a diameter at the land surface of about $20 \mathrm{~m}$, has a tidal range similar to ocean tides with little lag, indicating it has a high-permeability connection with the ocean. The sulfide and specific conductivity data shown in figure 5 were measured in water samples that were collected using tubing suspended from floats exactly $2 \mathrm{~m}$ below the water surface at three locations: about $1 \mathrm{~m}$ of the edge of the blue hole, in the center of the blue hole and midway between the edge and center of the blue hole. The change in specific conductivity though the tidal cycle suggests that the thickness of the fresh- water lens varies through the tidal cycle, probably as the sides of the blue hole slope slightly outward resulting in a wider diameter of the blue hole at higher elevations. As water levels rise during the flooding tide, the water within the blue hole flows into a wider portion of the blue hole, thereby thinning the fresh-water lens, which retains an approximately constant volume, and increases the specific conductivity $2 \mathrm{~m}$ below the water surface.

The difference in the sulfide concentrations from the edge to the center of the blue hole reflects the exchange of water from the blue hole water column with sulfiderich water within the matrix at the edge of the blue hole. At low tide, the head in the aquifer is elevated above the water level in the blue hole, creating a hydrologic gradient from the aquifer to the blue hole (Martin et al. 2012). This gradient causes water to flow from the aquifer into the blue hole. Sulfide is also generated within the water column because of sulfate reduction. Sulfide generated in situ as well as provided from the aquifer would be oxidized by dissolved oxygen in the upper portion of the water column. Only water at the edge of the blue hole with reduced $\mathrm{pH}$ values from sulfide oxidation is likely to exchange with matrix water and drive dissolution reactions. Water in the center of the blue hole is unlikely to dissolve calcite of the aquifer because of its lack of contact with the wall rock.

Exchange of water with low $\mathrm{pH}$ between the water column and the aquifer matrix derived from the oxidation of sulfide will allow dissolution through reaction mechanism similar to reaction 5. This reaction, although it dissolves carbonate, generates atmospheric $\mathrm{CO}_{2}$ rather than sequestering atmospheric $\mathrm{CO}_{2}$ such as occurs via a dissolution a reaction mechanism such as reaction 4. A source of $\mathrm{CO}_{2}$ from sulfide-driven dissolution could be important for the global carbon cycle, depending on the global magnitude of this process. If blue holes are the only location where this type of dissolution reaction occurs, the magnitude of $\mathrm{CO}_{2}$ produced is likely to be small. Reducing conditions also occur at the fresh water-salt water interface within the aquifer, which will cause sulfate reduction and subsequent sulfide oxidation (e.g., Bottrell et al. 1993). Sulfide-driven dissolution could thus be more widespread than the limited footprint provided by blue holes. A broad survey of well water chemistry could provide an estimate of the impact of this process outside of areas affected by blue holes. A more thorough sampling of the changes in the redox state beneath carbonate islands is required to estimate the net flux of these processes and whether dissolution by sulfuric acid provides an important source of atmospheric $\mathrm{CO}_{2}$. 


\section{SUMMARY AND REMAINING QUESTIONS}

The case studies described here reflect both sources and sinks of atmospheric $\mathrm{CO}_{2}$ in both marine and terrestrial carbonate karst systems. In addition, all of the dissolution and precipitation reactions involve either direct or indirect ecological control of the carbon concentrations through photosynthetic fixation of inorganic carbon and remineralization of organic carbon. The dissolution and precipitation of the solid carbonate minerals are also closely linked to the hydrology and hydrogeology of the region. Interactions between undersaturated water and the carbonate minerals of the aquifers require variability of head gradients allowing renewal of undersaturated water in contact with the minerals, or release of $\mathrm{CO}_{2}$ to the atmosphere to increase the saturation state of the carbonate minerals and to drive their precipitation.

Although these results indicate that carbonate minerals are linked to the global carbon cycle (e.g., Fig. 1), it is not clear if these reactions result in net changes in the fluxes of carbon throughout the cycle and thus will impact atmospheric concentrations. With changing global climates, however, the linkages between dissolution and precipitation within carbonate terrains may change. In the past, lower sea level would have exposed much of the surface of the platforms, which are currently submarine, to the atmosphere (Mylroie 1993). In these conditions, limited surface water and low freshwater lenses would be expected to alter ecological processes on the land surface, perhaps reducing primary productivity, concentration of organic carbon and its remineralization, and thus dissolution of the carbonate minerals through the formation of carbonic and sulfuric acids. Changes in sea level will have an important impact on the hydrogeology of low-lying carbonate platforms. Rising sea level will initially flood low-lying carbonate terrains and raise the water table, possibly increasing primary productivity, fixation of atmospheric $\mathrm{CO}_{2}$, and dissolution reactions as this organic carbon is remineralized. As sea level continues to rise, for example to elevations higher than modern sea level such as in the last interglacial (Lambeck et al. 2002), the low lying areas of what are now islands will be flooded with seawater and increase the deposition of marine carbonate. Consequently, even if the modern global carbon cycle has no net impact from the dissolution and precipitation of carbonate minerals, changes in ecological systems resulting from climate change impacts such as sea level variations and shifts in global precipitation patterns, may alter feedbacks between dissolution and precipitation within carbonate terrains, resulting in a net impact to the global carbon cycle.

\section{ACKNOWLEDGEMENTS}

Thanks to Thomas and Erin Rothfuss and staff at the Gerace Research Centre for their help and logistical support during field work in the Bahamas. Thanks also to John Mylroie and Bill Jones for extremely helpful reviews of an early version of this manuscript. We acknowledge financial support for this work from the National Sci- ence Foundation, grant numbers EAR-0910794 and EAR-0838369, as well as Geological Society of America, grant number 9821-12. Acknowledgment is also made to the Donors of the American Chemical Society Petroleum Research Fund for partial support of this research.

\section{REFERENCES}

Adams, P.N., Opdyke, N.D. \& J. M. Jaeger, 2010: Isostatic uplift driven by karstification and sea-level oscillation: Modeling landscape evolution in north Florida.- Geology 38, 531-534.

Alley, R.B., Clark, P.U., Huybrechts, P. \& I. Joughin, 2005: Ice-sheet and sea-level changes. - Science 310, 456-460.
Berger, W.H., 1982: Increase of carbon dioxide in the atmosphere during deglaciation: the coral reef hypothesis.- Naturwissenschaften $69,87-88$.

Berner, R.A., Lasaga, A.C. \& R.M. Garrels, 1983: The carbonate-silicate geochemical cycle and its effect on atmospheric carbon dioxide over the past 100 million years.- Am. J. Sci 283, 641-683. 
Bottrell, S.H., Carew, J.L. \& J.E. Mylroie, 1993: Inorganic and bacteriogenic origins for sulfate crusts in flank margin caves, San Salvador Island, Bahamas, Proceedings of the Sixth Symposium on the Geology of the Bahamas, B. White, San Salvador Island, Bahamas, Bahamian Field Station, Ltd. 6, 17-21.

Cohen, M.J., Heffernan, J.B., Albertin, A. \& J.B. Martin, 2012: Inference of riverine nitrogen processing from longitudinal and diel variation in dual nitrate isotopes.- Jour. Geophys. Res. 117, doi:10.1029/2011JG001715.

de Montety, V., Martin, J.B., Cohen, M.J. Foster, C.R. \& M.J. Kurz, 2011: Influence of diel biogeochemical cycles on carbonate equilibrium in a karst river.Chemical Geology 283, 31-43.

Falkowski, P., Scholes, R.J., Boyle, E., Canadell, J., Canfield, D., Elser, J., Gruber, N., Hibbard, K., Halgberg, P. \& S. Linder, 2000: The global carbon cycle: a test of our knowledge of earth as a system.- science 290, 291-296.

Ford, D. \& P. Williams, 2007: Karst Hydrogeology and Geomorphology, John Wiley and Sons, pp. 562, West Sussex,

Gulley, J., Martin, J.B., Screaton, E.J. \& P.J. Moore, 2011: River reversals into karst springs: A model for cave enlargement in eogenetic karst aquifers.- Geological Society of America Bulletin 123, 467.

Gulley, J.D., Martin, J.B., Spellman, P., Moore, P.J. \& E.J. Screaton, 2012: Influence of partial confinement and Holocene river formation on groundwater flow and dissolution in the Florida carbonate platform.Hydrological Processes.

Heffernan, J.B. \& M.J. Cohen, 2011: Direct and indirect coupling of primary production and diel nitrate dynamics in a subtropical spring-fed river.- Limnology and Oceanography 55, 677.

Hill, A.C., 1987: Geology of Carlsbad Cavern and other caves in the Guadalupe Mountains, New Mexico and Texas.- Signature 142735, 36.

Hill, C.A., 1990: Sulfuric Acid Speleogenesis of Carlsbad Cavern and Its Relationship to Hydrocarbons, Delaware Basin, New Mexico and Texas (1).- AAPG Bulletin 74, 1685-1694.

Hoegh-Guldberg, O., Mumby, P.J., Hooten, A.J., Steneck, R.S., Greenfield, P., Gomez, E., Harvell, C.D., Sale, P.F., Edwards, A.J. \& K. Caldeira, 2007: Coral reefs under rapid climate change and ocean acidification.- Science 318, 1737-1742.

Keeling, C.D. \& T.P. Whorf, 2005: Atmospheric $\mathrm{CO}_{2}$ records from sites in the SIO air sampling network.Trends: A compendium of data on global change 2009.
Kohout, F.A., 1965: A hypothesis concerning the cyclic flow of salt water related to geothermal heating in the Florida Aquifer.- New York Academy of Science Transactions 28, 249-271.

Lambeck, K., Esat, T.M. \& E.K. Potter, 2002: Links between climate and sea levels for the past three million years.- Nature 419, 199-206.

Liu, Z., Dreybrodt, W. \& H. Liu, 2011: Atmosheric $\mathrm{CO}_{2}$ sink: silicate weatering or carbonate weathering.Applied Geochemistry 26, 5292-5294.

Liu, Z., Dreybrodt, W. \& H. Wang, 2010: A new direction in effective accounting for the atmospheric $\mathrm{CO} 2$ budget: Considering the combined action of carbonate dissolution, the global water cycle and photosynthetic uptake of DIC by aquatic organisms.- Earth-Science Reviews 99, 162-172.

Mann, M.E., Bradley, R.S. \& M.K. Hughes, 1998: Globalscale temperature patterns and climate forcing over the past six centuries.- Nature 392, 779-787.

Martin, J.B. \& R.W. Dean, 2001: Exchange of water between conduits and matrix in the Floridan Aquifer.Chemical Geology 179, 145-165.

Martin, J.B., Gulley, J. \& P. Spellman, 2012: Tidal pumping of water between Bahamian blue holes, aquifers, and the ocean.- Journal of Hydrology 416-417, $28-38$.

Martin, J.B. \& P.J. Moore, 2008: Sr concentrations and isotope ratios as tracers of ground-water circulation in carbonate platforms: Examples from San Salvador Island and Long Island, Bahamas.- Chemical Geology 249, 52-65.

Mylroie, J.E., 1993: Carbonate deposition/dissolution cycles and carbon dioxide flux in the Pleistocene.In: B. White (eds), Proceedings of the Sixth Symposium on the Geology of the Bahamas, Bahamian Field Station, San Salvador, Bahamas, Bahamian Field Station, Ltd.

Mylroie, J.E., Carew, J.L. \& A.I. Moore, 1995: Blue Holes: Definition and genesis.- Carbonates and Evaporites $10,225-233$.

Mylroie, J.E., Carew, J.L. \& H.L. Vacher, 1995: Karst development in the Bahamas and Bermuda.- In: H. A. Curran and B. White (eds), Terrestrial and Shallow Marine Geology of the Bahamas and Bermuda.Geological Society of America. 300: 251-267, Boulder, Colorado.

Opdyke, N.D., Spangler, D.P., Smith, D.L., Jones, D.S. \& R.C. Lindquist, 1984: Origin of the epeirogenic uplift of Pliocene-Pleistocene beach ridges in Florida and development of the Florida karst.- Geology 12, 226-228. 
Orr, J. C., V. J. Fabry, O. Aumont, L. Bopp, S. C. Doney, R. A. Feely, A. Gnanadesikan, N. Gruber, A. Ishida \& F. Joos, 2005: Anthropogenic ocean acidification over the twenty-first century and its impact on calcifying organisms.- Nature 437, 681-686.

Overpeck, J. T., B. L. Otto-Bliesner, G. H. Miller, D. R. Muhs, R. B. Alley \& J. T. Kiehl, 2006: Paleoclimatic evidence for future ice-sheet instability and rapid sea-level rise.- Science 311, 1747-1750.

Raymo, M. E., W. F. Ruddiman \& P. N. Froelich, 1988: Influence of late Cenozoic mountain building on ocean geochemical cycles.- Geology 16, 649-653.

Rosenau, J. C., G. L. Faulkner, J. Charles W. Hendry \& R. W. Hull, 1977: The Springs of Florida, Department of Natural Resources, Bulletin \#31, pp. 461, Tallahassee, Florida,

Schwabe, S. \& R. A. Herbert, 2004: Black Holes of the Bahamas: what they are and why they are black.Quaternary International 121, 3-11.

Scott, T. M., 1988: The lithostratigraphy of the Hawthorn Group (Miocene of Florida), Florida Geological Survey Bulletin, pp. 147,

Scott, T. M., 1992: A Geological Overview of Florida, Florida Geological Survey, pp. 78,

Scott, T. M., G. H. Means, R. P. Meegan, R. C. Means, S. B. Upchurch, R. E. Copeland, J. Jones, T. Roberts \& A. Willet, 2004: Springs of Florida, Tallahassee, Florida, Florida Geological Survey. 66, 377.
Sealey, N. E., 2006: Bahamian landscapes; an introduction to the physical geography of the Bahamas, Macmillan Publishers, pp. 174, Oxford,

Solomon, S., D. Qin, M. Manning, Z. Chen, M. Marquis, K. B. Averyt, M. Tignor \& H. L. Miller, 2007: IPCC.Intergovernmental Panel on Climate Change. Climate Change.

Stoessell, R. K., W. C. Ward, B. H. Ford \& J. D. Schuffert, 1989: Water chemistry and $\mathrm{CaCO} 3$ dissolution in the saline part of an open-flow mixing zone, coastal Yucatan Peninsula, Mexico:-- Geological Society of America Bulletin 101, 159-169.

Stumm, W. \& J. J. Morgan, 1996: Aquatic Chemistry, John Wiley and Sons, Inc., pp. 1022, New York,

Vacher, H. L. \& J. E. Mylroie, 2002: Eogenetic karst from the perspective of an equivalent porous medium.Carbonates and Evaporites 17, 182-196.

Whitaker, F. F. \& P. L. Smart, 1990: Active circulation of saline ground waters in carbonate platforms: Evidence from the Great Bahama Bank.- Geology 18, 200-204.

Whitaker, F. F. \& P. L. Smart, 1997: Groundwater circulation and geochemistry of a karstified bank-marginal fracture system, South Andros Island, Bahamas.Journal of Hydrology 197, 293-315. 